\title{
Plasmids and factors associated with virulence in environmental isolates of Vibrio cholerae non-01 in Bangladesh
}

\author{
J.L. BARJA, YSABEL SANTOS, I. HUQ*, RITA R. COLWELL† and ALICIAE. TORANZO
}

Departamento de Microbiologia y Parasitologia, Facultad de Biologia, Universidad de Santiago de Compostela 15706, Spain. *International Centre for Diarrhoeal Disease Research, Dacca, Bangladesh and +Department of Microbiology, University of Maryland, College Park 20742, USA

\begin{abstract}
Summary. Plasmid profiles and factors associated with toxigenicity in 51 strains of Vibrio cholerae non-O1 isolated from water samples collected in Bangladesh were analysed. Eleven $(21.5 \%)$ strains were found to harbour at least one plasmid of $1.7-$ $115 \mathrm{Mda}$; seven of these strains shared a 115-Mda plasmid. Six of 13 strains tested gave positive cytotoxic and enterotoxic responses. However, two non-cytotoxic strains were enterotoxigenic. Only three of the six cytotoxic and enterotoxic strains caused haemagglutination of human erythrocytes which indicated that toxin production and haemagglutinating activity were unrelated in these $V$. cholerae non-O1 strains. Conjugal transfer assays demonstrated that the 115-Mda plasmid harboured by some of the toxigenic $V$. cholerae non-O1 strains carried genes coding for antibiotic resistance and cytotoxin production but not for enterotoxin production. However, this plasmid was also carried by non-toxigenic strains. Some other strains carrying no plasmids or only small-mol.-wt plasmids, were found to be toxigenic. Therefore, toxin production is not plasmid-mediated in all $V$. cholerae non-O1 strains. Regardless of their pathogenic potential, $V$. cholerae non-O1 strains possessed the capacity to grow in conditions of iron limitation and, under these conditions, synthesis of at least two new outer-membrane proteins was induced.
\end{abstract}

\section{Introduction}

At present there is little doubt about the autochthonous aquatic nature of the non-O1 serovars of Vibrio cholerae. $V$. cholerae non-O1 strains are widely distributed in marine environments, especially bays, estuaries and other brackish waters, and in shellfish. ${ }^{1-4}$ Ecological studies ${ }^{1,5}$ seem to indicate that $V$. cholerae non-O1 strains are not associated with sewage pollution, being more abundant in the natural environment where they are associated frequently with the microand macro-flora and fauna of fresh and coastal waters. ${ }^{6,7}$

The number of reports of diarrhoeal illness in different countries caused by $V$. cholerae non-O1 strains has increased over the past decade as a result of the recognition of their importance as pathogens for $\operatorname{man}^{8-10}$ and animals. ${ }^{3,11,12} \mathrm{Al}-$ though it has been reported ${ }^{13}$ that $V$. cholerae nonO1 strains can produce more than one type of

Received 2 March 1990; accepted 19 April 1990. cholera-like enterotoxin, the pathophysiological mechanism underlying $V$. cholerae non-Ol induced diarrhoea remains largely unknown because many strains do not produce cholera toxin (CT). ${ }^{1,2,12,14}$ Furthermore, whether clinical or environmental isolates possess the higher enteropathogenic potential is controversial. ${ }^{14-16}$

In the work reported here, several factors associated with the toxigenicity of environmental $V$. cholerae non- $\mathrm{O} 1$ isolates from waters in Bangladesh were studied and the drug resistance patterns and plasmid profiles of these strains were analysed.

\section{Materials and methods}

\section{Bacterial strains and antimicrobial susceptibility tests}

In this study, $51 \mathrm{~V}$. cholerae non-O1 strains isolated from water samples collected at three different sites in Bangladesh-Dacca (D), Matlab (M) and Teknaf(TK)were examined. Strains were cultured routinely at $25^{\circ} \mathrm{C}$ in Trypticase Soy Broth (TSB; Oxoid, CM129) supplemented with $\mathrm{NaCl} 1 \%$, and maintained on Trypticase Soy Agar (TSA; Oxoid, CM131). Strains were identified by the procedures and criteria of West and Colwell. ${ }^{17}$ 
Resistance of the isolates to antimicrobial agents was determined by disk diffusion on Mueller-Hinton Agar (MHA; Oxoid, CM 337) with disks containing ( $\mu \mathrm{g} / \mathrm{disk}$ ); ampicillin 10, chloramphenicol 30, gentamicin 10, kanamycin 30 , tetracycline 30 , streptomycin 10 , trimethoprimsulphamethoxazole $1 \cdot 25 / 23 \cdot 7$ and sulphathiazole 1000 .

The numbers and characteristics of the Vibrio isolates are shown in table I.

\section{Cytotoxicity assays}

Supernates obtained by centrifugation $(10000 g$ for 5 $\mathrm{min}$ ) of bacteria cultured in TSB for $18 \mathrm{~h}$ at $25^{\circ} \mathrm{C}$ were filtered (0.2 $\mu \mathrm{m}$; Millipore membrane) and tested for cytotoxicity on Y-1 mouse adrenal cells and Chinese Hamster Ovary ( $\mathrm{CHO}$ ) cells. Assays were performed as described elsewhere. ${ }^{1}$ Cytotoxic activity was indicated by rounding, shrinking, granule formation and vacuolisation of the cells. In these assays, the filtered culture supernate of $V$. cholerae LA 4808 (cholera enterotoxin positive; $\mathrm{CT}^{+}$) was included as a positive control.

\section{Production of enterotoxins}

Enterotoxin activity of cytotoxic and non-cytotoxic strains of $\boldsymbol{V}$. cholerae non-O1 was measured by the suckling mouse assay following essentially the procedures of Nishibuchi and Seidler. ${ }^{18}$ Filtered supernates $(100 \mu \mathrm{l})$ of bacterial cultures were administered to 2-4-day-old mice intra-gastrically. After incubation for $3 \mathrm{~h}$ at $30^{\circ} \mathrm{C}$, the animals were killed and the ratio of intestinal weight to remaining body weight (IW/BW) was measured. Ratios greater than 0.08 were regarded as indicating enterotoxin production. Filtered culture supernates of $V$. cholerae LA $4808\left(\mathrm{CT}^{+}\right)$and Escherichia coli $\mathrm{K} 12185$ $\mathrm{ST}^{-} \mathrm{LT}^{-}$(thermostable and thermolabile enterotoxin negative) were used as controls.

Culture filtrates of some enterotoxin-producing strains were heated at $100^{\circ} \mathrm{C}$ for $30 \mathrm{~min}$ and the $\mathrm{IW} / \mathrm{BW}$ ratios induced by the heated and unheated filtrates were determined.

\section{Haemagglutination assays and haemolytic activity}

Human blood group $\mathrm{O}$ was collected by venepuncture and placed into Alsever's solution. For haemagglutination assays, blood cells were washed three times in phosphatebuffered saline (PBS), $\mathrm{pH} \mathrm{7.4,} \mathrm{and} \mathrm{a} 3 \% \mathrm{v} / \mathrm{v}$ final suspension was prepared in this solution. Bacterial strains were grown at $25^{\circ} \mathrm{C}$ on TSA and on blood agar prepared from TSA with citrated sheep blood $5 \%$. After 24 and $48 \mathrm{~h}$, suspensions of the bacteria were prepared in PBS and adjusted to an optical density (OD) to yield c. $10^{9}$ cells $/ \mathrm{ml}$. Slide agglutination tests were performed essentially as described previously. ${ }^{19}$ Strains were considered to be non-haemagglutinating if agglutination did not occur within $10 \mathrm{~min}$. The Minimum Haemagglutinating Dose (MHD) was defined as the smallest number of bacterial cells $/ \mathrm{ml}$ that gave visible haemagglutination
Table I. Drug-resistance markers and plasmid profiles of $V$. cholerae non-O1 strains isolated from water samples in Bangladesh

\begin{tabular}{|c|c|c|c|}
\hline Strain no. & $\begin{array}{c}\text { Presence } \\
\text { (and number) } \\
\text { of plasmids }\end{array}$ & 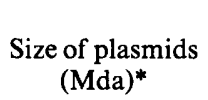 & $\begin{array}{c}\text { Resistance } \\
\text { patterns }\end{array}$ \\
\hline M-17151 & $+(1)$ & 115 & Am K S St Te \\
\hline M-17153 & $+(1)$ & 115 & $\mathrm{Am} \mathrm{K} \mathrm{S} \mathrm{St} \mathrm{Te}$ \\
\hline M-17214 & - & - & $\mathrm{St}$ \\
\hline M-17221 & - & - & St \\
\hline M-17225 & - & - & Am S St \\
\hline TK-17065 & $+(3)$ & $115 ; 20 ; 1.7$ & $\mathrm{Am} \mathrm{St} \mathrm{Te}$ \\
\hline TK-17068 & $+(1)$ & 115 & $\mathrm{Am}$ \\
\hline TK-17081 & - & - & $\mathrm{Am} \mathrm{St}$ \\
\hline TK-17085 & - & - & $\mathrm{Am}$ \\
\hline TK-17121 & $+(1)$ & $4 \cdot 6$ & Am S St \\
\hline TK-17599 & $+(3)$ & $115 ; 28 ; 4.8$ & Am St Te \\
\hline TK-17600 & - & - & Am K S St \\
\hline TK-17604 & - & - & St \\
\hline TK-17610 & - & - & $\mathrm{Am} \mathrm{St}$ \\
\hline TK-17747 & - & - & Am S \\
\hline TK-17750 & - & - & Am S \\
\hline TK-17751 & - & - & $\mathrm{Am} \mathrm{St} \mathrm{Te}$ \\
\hline TK-17752 & $+(1)$ & 115 & $\mathrm{Am} \mathrm{St}$ \\
\hline TK-17755 & - & - & $\mathrm{Am} \mathrm{St}$ \\
\hline TK-17841 & $+(1)$ & 18 & $\mathrm{Am} \mathrm{St}$ \\
\hline D-17372 & - & $\ldots$ & St \\
\hline D-17382 & - & - & S St \\
\hline D-17387 & - & - & St \\
\hline D-17401 & - & - & $\mathrm{Am} \mathrm{St}$ \\
\hline D-17409 & 一 & - & $\ldots$ \\
\hline D-17410 & - & - & $\ldots$ \\
\hline D-17417 & - & - & St \\
\hline D-17419 & - & - & $\ldots$ \\
\hline D-17421 & - & - & $\ldots$ \\
\hline D-17424 & - & - & $\ddot{\text { St }}$ \\
\hline D-17432 & - & - & St \\
\hline D-17435 & - & - & S St \\
\hline D-17447 & - & - & St \\
\hline D-17450 & - & - & \\
\hline D-17451 & $+(2)$ & $115 ; 3.4$ & $\mathrm{Am} \mathrm{S} \mathrm{St} \mathrm{Te}$ \\
\hline D-17467 & - & - & St \\
\hline D-17492 & 一 & - & St \\
\hline D-17642 & $+(1)$ & $2 \cdot 5$ & St \\
\hline D-17833 & - & - & $\ldots$ \\
\hline D-17892 & - & 一 & St \\
\hline D-17897 & $+(2)$ & $3 \cdot 4 ; 2$ & $\mathrm{Am} \mathrm{St}$ \\
\hline D-17912 & - & - & St \\
\hline D-17914 & - & - & St \\
\hline D-17917 & - & - & St \\
\hline D-18009 & - & - & $\ldots$ \\
\hline D-18045 & - & - & $\ldots$ \\
\hline D-18046 & - & - & $\ldots$ \\
\hline D- 18047 & - & - & $\cdots$ \\
\hline D- 18048 & - & - & $\cdots$ \\
\hline D- 18050 & - & - & $\cdots$ \\
\hline D-18076 & - & - & St \\
\hline
\end{tabular}

D, Dacca; M, Matlab; TK, Teknaf.

Am, ampicillin; K, kanamycin; S, streptomycin; St, sulphathiazole; Te, tetracycline.

..., Sensitive strains.

* Mol. wt in Mda, determined by agarose gel electrophoresis. 
in $10 \mathrm{~min}$ and the haemagglutination power of a culture was calculated as $10^{11} / \mathrm{MHD} .^{20}$ Inhibition of haemagglutination was performed in the same way as the agglutination test but with bacterial suspensions containing 10 MHD in PBS supplemented with D-mannose (Sigma) $1 \% \mathrm{w} / \mathrm{v}$.

Haemolysin production by the $V$. cholerae non-O1 strains was detected by eye on TSA plates supplemented with defibrinated sheep blood $5 \%$ after incubation for 24 and $48 \mathrm{~h}$ at $25^{\circ} \mathrm{C}$.

\section{Detection of plasmids by agarose gel electrophoresis}

Plasmid DNA was isolated from small volumes (3$4 \mathrm{ml}$ ) of bacterial cultures, following basically the method of Kado and $\mathrm{Liu}^{21}$ with several modifications. ${ }^{22}$ DNA samples $(25 \mu \mathrm{l})$ were electrophoresed through agarose (type I, Sigma) $0.7 \%$ in Tris-acetate buffer ( $40 \mathrm{~mm}$ Tris, $2 \mathrm{mM} \mathrm{Na}{ }_{2}$-EDTA, adjusted to $\mathrm{pH} 7.9$ with glacial acetic acid) at $150 \mathrm{~V}$, for $4 \mathrm{~h}$ in a horizontal apparatus. The gels were stained in ethidium bromide $0.5 \mu \mathrm{g} / \mathrm{ml}$ of water. Plasmids used as markers were: TP $116(143.7 \mathrm{Mda})$, R40a (96 Mda), R1 (62 Mda), R27 (112 Mda), and plasmids from $E$. coli V517 1.4-35.8 Mda.

\section{Curing experiments}

To assess the possible relationship between plasmid content and phenotypic traits, $V$. cholerae non-O1 strains were treated with several curing agents: mitomycin $\mathrm{C}$ (Sigma), ethidium bromide (Sigma), and sodium dodecyl sulphate (SDS; Sigma). Cells were grown for $24 \mathrm{~h}$ at $25^{\circ} \mathrm{C}$ in broth containing mitomycin C $0.5,0.05$ and $0.005 \mu \mathrm{g} /$ $\mathrm{ml}$, or ethidium bromide $0.4,0.04$ and $0.004 \mathrm{mg} / \mathrm{ml}$. The SDS concentrations used were $1 \%$ and $0 \cdot 1 \% \mathrm{w} / \mathrm{v}$. After these treatments, cultures were plated on TSA and the colonies were replica-plated on to the same media with and without the appropriate antibiotics. Only those colonies were picked from the antibiotic-free master plate whose replicas failed to grow on media containing antibiotics, and their plasmid content was determined. In addition, colonies of toxigenic strains were selected at random from the master plates and their cytotoxic activity determined.

\section{Conjugal-transfer assays}

Four multiresistant $V$. cholerae non-O1 strains, each carrying a 115-Mda plasmid, were used as potential donors in mating experiments with $E$. coli $\mathrm{K} 12$ $185 \mathrm{Na}^{\mathrm{r}} \mathrm{lac}^{+} \mathrm{ST}^{-} \mathrm{LT}^{-}$(nalidixic acid resistant, lactose positive) as the recipient strain. Matings were performed in TSB at $25^{\circ} \mathrm{C}$ as previously described. ${ }^{23}$ At 4 and $18 \mathrm{~h}$ after the start the experiment, each mating mixture was plated on BTB-lactose agar-Nutrient Agar (Difco) containing bromothymol blue $0.0045 \%$ and lactose $1 \%$ supplemented with nalidixic acid $100 \mu \mathrm{g} / \mathrm{ml}$ and selected antibiotics (kanamycin, streptomycin and tetracycline) $25 \mu \mathrm{g} / \mathrm{ml}$. The frequency of transfer was calculated as the number of transconjugants/initial number of donors $/ \mathrm{ml}$.
For the strains showing donor ability to $E$. coli, these conjugal studies were extended with the nalidixic acidresistant derivatives obtained from Aeromonas hydrophila 67-P-24, V. anguillarum PB-15 (fish pathogenic strains) and $V$. harveyi $\mathrm{K} \mathrm{N}-96$ as recipient strains.

Transconjugants isolated from each selective plate were checked for drug resistance and the presence of plasmids. The $E$. coli transconjugants were also assayed for cytotoxic (with Y-1 cells) and enterotoxic activities.

\section{Growth under iron-limiting conditions and analysis of cell-envelope proteins}

$V$. cholerae non-O1 strains were cultured in $\mathrm{M} 9$ minimal medium (composition in $\mathrm{g} / 1: \mathrm{Na}_{2} \mathrm{HPO}_{4}, 6 ; \mathrm{KH}_{2} \mathrm{PO}_{4}, 3$; $\mathrm{NaCl}, 5 ; \mathrm{NH}_{4} \mathrm{Cl}, 1 ; \mathrm{CaCl}_{2}, 0.0015 ; \mathrm{MgSO}_{4}, 0.012$; glucose, $5 ; \mathrm{pH} 7 \cdot 2$ ) supplemented with Casamino acids (Difco) $0.2 \% \mathrm{w} / \mathrm{v}$. The iron chelator ethylenediamine-di$o$-hydroxyphenylacetic acid (EDDA) (Sigma) was added to produce a concentration of $10 \mu \mathrm{M}$ to achieve the ironlimitation conditions.

Total and outer-membrane proteins were prepared as previously described. ${ }^{24,}{ }^{25}$ The outer membranes were obtained by treatment of the cell envelopes with Sarkosyl $1.5 \% \mathrm{w} / \mathrm{v}$ in $10 \mathrm{mM}$ Tris- $\mathrm{HCl}(\mathrm{pH} 8.0)$ at room temperature for $20 \mathrm{~min}$ to dissolve the inner membranes. Pellets from total cell envelopes or outer membranes were examined by sodium dodecyl sulphate-polyacrylamide gel electrophoresis (SDS-PAGE) on separating gels of acrylamide $12.5 \%$ and stacking gels of $3 \%$. Induction of new proteins under iron limitation was revealed by comparisons between the protein patterns of the strains grown in M9 minimal medium containing either $10 \mu \mathrm{M}$ EDDA or $10 \mu \mathrm{M} \mathrm{FeCl}_{3}$.

\section{Results}

\section{Cytotoxic and enterotoxic activities}

The cell-free culture supernates of 13 strains of $V$. cholerae non-O1 were tested for cytotoxic activity on Y-1 and $\mathrm{CHO}$ cells. Four strains showed a cytotoxic response similar to $V$. cholerae LA 4808 in both cell lines employed and two strains exhibited activity only on Y-1 cells (table II). Although culture supernates of some strains (D-17451, D-17447 and $\mathrm{D}-17642$ ) produced morphological changes in $\mathrm{CHO}$ or Y-1 cells within 6 or $8 \mathrm{~h}$, the extracts of other positive strains (M-17151, M-17153 and TK-17068) required $20 \mathrm{~h}$ to display the same degree of activity.

The enterotoxic activity of the supernates, as determined by the suckling mouse assay, revealed that all the cytotoxic $V$. cholerae non-O1 strains also produced enterotoxins. However, two of the noncytotoxic strains (TK-17121 and TK-17599) were also enterotoxigenic.

The enterotoxins produced by the $V$. cholerae 
Table II. Cytotoxic, enterotoxic and haemagglutinating activities of $V$. cholerae non-Ol and other strains

\begin{tabular}{|c|c|c|c|c|}
\hline \multirow[b]{2}{*}{ Strain no. } & \multicolumn{2}{|c|}{ Cytotoxic response* } & \multirow{2}{*}{$\begin{array}{c}\text { Enterotoxin activity } \\
\text { in suckling } \\
\text { mouse assay } \\
(\mathrm{IW} / \mathrm{BW}) \dagger\end{array}$} & \multirow[b]{2}{*}{$\begin{array}{l}\text { Haemagglutination } \\
\text { power } \ddagger\end{array}$} \\
\hline & $\mathrm{Y}-1$ & $\mathrm{CHO}$ & & \\
\hline M-17151 & + & + & $+(0.095)$ & $2.5 \times 10^{3}(\mathrm{R})$ \\
\hline M-17153 & + & + & $+(0.090)$ & $2.5 \times 10^{3}(\mathrm{R})$ \\
\hline TK-17068 & + & - & $+(0.084)$ & - \\
\hline TK-17065 & - & - & $-(0.070)$ & _- \\
\hline TK-17081 & - & ND & $-(0 \cdot 070)$ & - \\
\hline TK-17121 & - & - & $+(0.091)$ & - \\
\hline TK-17599 & - & - & $+(0.084)$ & - \\
\hline TK-17599-B§ & - & - & $+(0.088)$ & - \\
\hline TK-17752 & - & - & $-(0.071)$ & - \\
\hline TK-17841 & - & ND & ND & ND \\
\hline D-17447 & + & ND & $+(0.083)$ & - \\
\hline D- -17451 & + & + & $+(0 \cdot 10)$ & - \\
\hline $\begin{array}{l}\text { D-17642 } \\
\text { Controls }\end{array}$ & + & + & $+(0 \cdot 087)$ & $6.6 \times 10^{4}(\mathrm{R})$ \\
\hline V. cholerae LA4808 & + & + & $+(0.11)$ & $8.3 \times 10^{4}(\mathrm{R})$ \\
\hline E. coli $\mathrm{K} 12185$ & - & - & $-(0.060)$ & ND \\
\hline
\end{tabular}

ND, Not determined.

* Responses of cell lines to culture supernates were recorded after treatment for $6-20 \mathrm{~h}$; + , a morphological response exhibited by $>75 \%$ of the cells; - , no morphological response.

$\dagger$ Fluid accumulation ratio (intestinal weight remaining/body weight). Results are expressed as mean values of three different experiments for each strain.

$\ddagger$ Results were obtained from cultures grown on TSA at $25^{\circ} \mathrm{C}$ for $48 \mathrm{~h}$. (R), indicates haemagglutination resistant to inhibition by D-mannose; -, non-haemagglutinating.

$\S$ Plasmid-less strain derived from the parental $V$. cholerae non-O1 strain TK-17599.

non-O1 strains differed in their stability to heat Whereas the enterotoxin from strain D-17451 was heat-labile, those produced by strains M-17151 and M-17153 were heat stable.

\section{Haemagglutinating and haemolytic activities}

Only three strains (M-17151, M-17153, and D17642) together with $V$. cholerae LA 4808 displayed strong agglutination of human erythrocytes that was resistant to inhibition by D-mannose. These strains were also cytotoxic and enterotoxic. However, the other toxigenic strains were unable to haemagglutinate human $\mathrm{O}$ erythrocytes.

To detect possible differences in adhesin expression under in-vitro conditions, the haemagglutination powers of the strains grown on TSA and blood agar were compared and found to be the same. Transient haemagglutination by the negative strains was not observed after growth on either of these media.

Analysis of the haemolytic activity of these estuarine vibrios revealed that only strains with cytotoxic activity produced haemolysis of sheep erythrocytes (data not shown).

\section{Plasmid content of $V$. cholerae non-O1 strains}

Analysis of the plasmid content of the $V$. cholerae non-O1 strains revealed that $11(21.5 \%)$ strains carried one or more plasmids of $1.7-115 \mathrm{Mda}$ (table I). Seven strains carried the 115-Mda high-mol.-wt plasmid and three strains carried only small ( $<5 \mathrm{Mda}$ ) mol.-wt plasmids. Only in the $V$. cholerae non-O1 strain TK-17599 was a 28-Mda plasmid band detected.

\section{Curing experiments}

To determine relationships, if any, between plasmid carriage and antibiotic resistance or cytotoxic properties or both, curing experiments were performed with four of the 11 plasmid-bearing strains-D-17642, M-17151 and D-17451, which had exhibited cytotoxic activity on Y-1 and $\mathrm{CHO}$ cells, and strain TK-17599 which had not. Tetra- 
cycline-sensitive derivatives were isolated only from $V$. cholerae non-O1 strain TK-17599 after growth in media containing either ethidium bromide or mitomycin. The loss of tetracycline resistance was accompanied by the loss of the smallmol.-wt plasmid ( $4.8 \mathrm{Mda})$ in all the susceptible derivates but their enterotoxigenic abilities were not modified.

Because neither drug-sensitive nor plasmid-less derivatives of the other Vibrio strains were isolated, it was not determined whether drug resistance or cytotoxic activity is plasmid-mediated in these strains.

\section{Mating assays}

In an attempt to characterise the 115-Mda plasmid present in a group of multiresistant $V$. cholerae non-O1 strains, four of these strains were mated with $E$. coli $\mathrm{K} 12185 \mathrm{Na}^{\mathrm{r}}$. The results (table III) show that only the toxigenic strains M-17151 and M-17153 transferred drug resistance genes coding for streptomycin, kanamycin and sulphathiazole and did so with frequencies of $c .10^{-4}$. Furthermore, both strains transmitted the 115-Mda plasmid to the environmental Aeromonas and Vibrio strains used as recipients, with similar or higher frequencies than obtained with $E$. coli.

Interestingly, culture filtrates of the transconjugant $E$. coli strains displayed cytotoxic activity on
Y-1 cells similar to that given by those of the respective donor strains. However, culture filtrates of these transconjugants did not exhibit enterotoxic activity, which indicated that the enterotoxin production was not plasmid mediated in these $V$. cholerae non-O1 strains.

By analysis of the plasmid content of transconjugants we demonstrated a correlation between the specific 115-Mda plasmid and the antibiotic resistances and cytotoxin production transferred. The fact that other non-toxigenic strains with different drug resistance patterns also carried the $115-\mathrm{Mda}$ plasmid, indicated that the plasmid coded for different phenotypic traits in these $V$. cholerae nonO1 strains.

\section{Induction of outer-membrane proteins in conditions of iron limitation}

We compared the ability of selected strains, with and without toxic activities (table II) to grow in the presence or absence of iron (as $\mathrm{FeCl}_{3}$ ). Growth of all strains tested was found to be independent of the presence of iron in the medium. Analysis of total cell envelopes, as well as outer membranes, showed that an intense major outer-membrane protein of $25 \mathrm{Kda}$ was common to most of the strains and that, among the enterotoxin-forming strains tested, three different patterns of outermembrane proteins were induced in conditions of

Table III. Conjugal transfer assays of drug-resistance factors from selected $V$. cholerae non-O1 strains to E. coli K12 and different environmental Aeromonas and Vibrio strains

\begin{tabular}{|c|c|c|c|c|c|c|c|c|c|}
\hline $\begin{array}{l}\text { Donor } \\
\text { strain }\end{array}$ & $\begin{array}{l}\text { Drug } \\
\text { resistance } \\
\text { pattern* }\end{array}$ & $\begin{array}{l}\text { Plasmid } \\
\text { content } \\
\text { (Mda) }\end{array}$ & $\begin{array}{c}\text { Selective } \\
\text { resistance } \\
\text { markers }\end{array}$ & \multicolumn{4}{|c|}{ Transfer frequency $\ddagger$ to recipient strain } & $\begin{array}{l}\text { Resistance } \\
\text { transferred }\end{array}$ & $\begin{array}{c}\text { Plasmid } \\
\text { (Mda) } \\
\text { transferred }\end{array}$ \\
\hline \multicolumn{10}{|c|}{ Toxigenic strains } \\
\hline \multicolumn{2}{|c|}{ M-17151 Am K S St Te } & 115 & $\begin{array}{c}K \\
S \\
T e\end{array}$ & $\begin{array}{c}1.5 \times 10^{-4} \\
8.0 \times 10^{-5} \\
\ldots\end{array}$ & $\begin{array}{c}2.0 \times 10^{-2} \\
4.5 \times 10^{-3} \\
\ldots\end{array}$ & $\begin{array}{c}2 \cdot 0 \times 10^{-3} \\
\mathrm{NA} \\
\ldots\end{array}$ & $\begin{array}{c}1.4 \times 10^{-4} \\
\text { NA } \\
\ldots\end{array}$ & $\begin{array}{l}\text { K S St } \dagger \\
\text { K S St } \uparrow\end{array}$ & $\begin{array}{l}115 \\
115\end{array}$ \\
\hline \multicolumn{10}{|c|}{ Non-cytotoxic strains } \\
\hline $\begin{array}{l}\text { TK-17065 } \\
\text { TK-17599 }\end{array}$ & $\begin{array}{l}\text { Am St Te } \\
\text { Am St Te }\end{array}$ & $\begin{array}{l}115 ; 20 ; 1.7 \\
115 ; 28 ; 4.8\end{array}$ & $\begin{array}{l}\mathrm{Te} \\
\mathrm{Te}\end{array}$ & $\begin{array}{l}\ldots \\
\ldots\end{array}$ & $\begin{array}{l}\text { NT } \\
\text { NT }\end{array}$ & $\begin{array}{l}\text { NT } \\
\text { NT }\end{array}$ & $\begin{array}{l}\text { NT } \\
\text { NT }\end{array}$ & & \\
\hline
\end{tabular}

\footnotetext{
NA, Not applicable.

..., No transconjugants recovered.

NT, Not tested.

* See footnote to table I.

$\ddagger$ Transfer frequencies expressed as the number of transconjugants/initial donor cell $/ \mathrm{ml}$.

$\uparrow$ The transconjugants in $E$. coli showed also cytotoxic activity on Y-1 cells.
} 
iron limitation (see figure). Enterotoxigenic and cytotoxigenic strains $\mathbf{M}-17153, \mathbf{M}-17151$ and $\mathrm{D}$ 17642 showed induction of three proteins of 76, 74 and $72 \mathrm{Kda}$ (figure; lanes $B_{2}, C_{2}$ and $G_{2}$ ) whereas in strain D-17451, outer-membrane proteins of 72, 70 and $65 \mathrm{Kda}$ were induced (figure; lane $\mathrm{D}_{2}$ ). For strains TK-17599 and TK-17121, with only enterotoxic activity, the mol. wts of the induced proteins were 76 and $70 \mathrm{Kda}$ (figure; lanes $\mathrm{E}_{2}, \mathrm{H}_{2}$ ). Differences in membrane proteins between parental and plasmid-cured derivative isolates of $V$. cholerae non-O1 TK-17599 were not detected (figure; lanes E, F).
All of the outer-membrane proteins induced in $V$. cholerae non-O1 strains were different in mol. wt from the OM2 protein $(86 \mathrm{Kda})$ mediated by the virulence plasmid pJM1 and from the chromosomemediated OM3 protein $(79 \mathrm{Kda})$ present in $V$. anguillarum strain $775^{24}$ (figure; lane $\mathrm{A}_{2}$ ).

\section{Discussion}

Serology is not a definitive indicator of pathogenicity because $V$. cholerae $\mathrm{O} 1$ strains have been isolated that do not possess the genetic potential for

\section{$A_{1} A_{2} B_{1} B_{2} C_{1} C_{2} D_{1} D_{2} E_{1} E_{2} F_{1} F_{2} G_{1} G_{2} H_{1} H_{2}$}

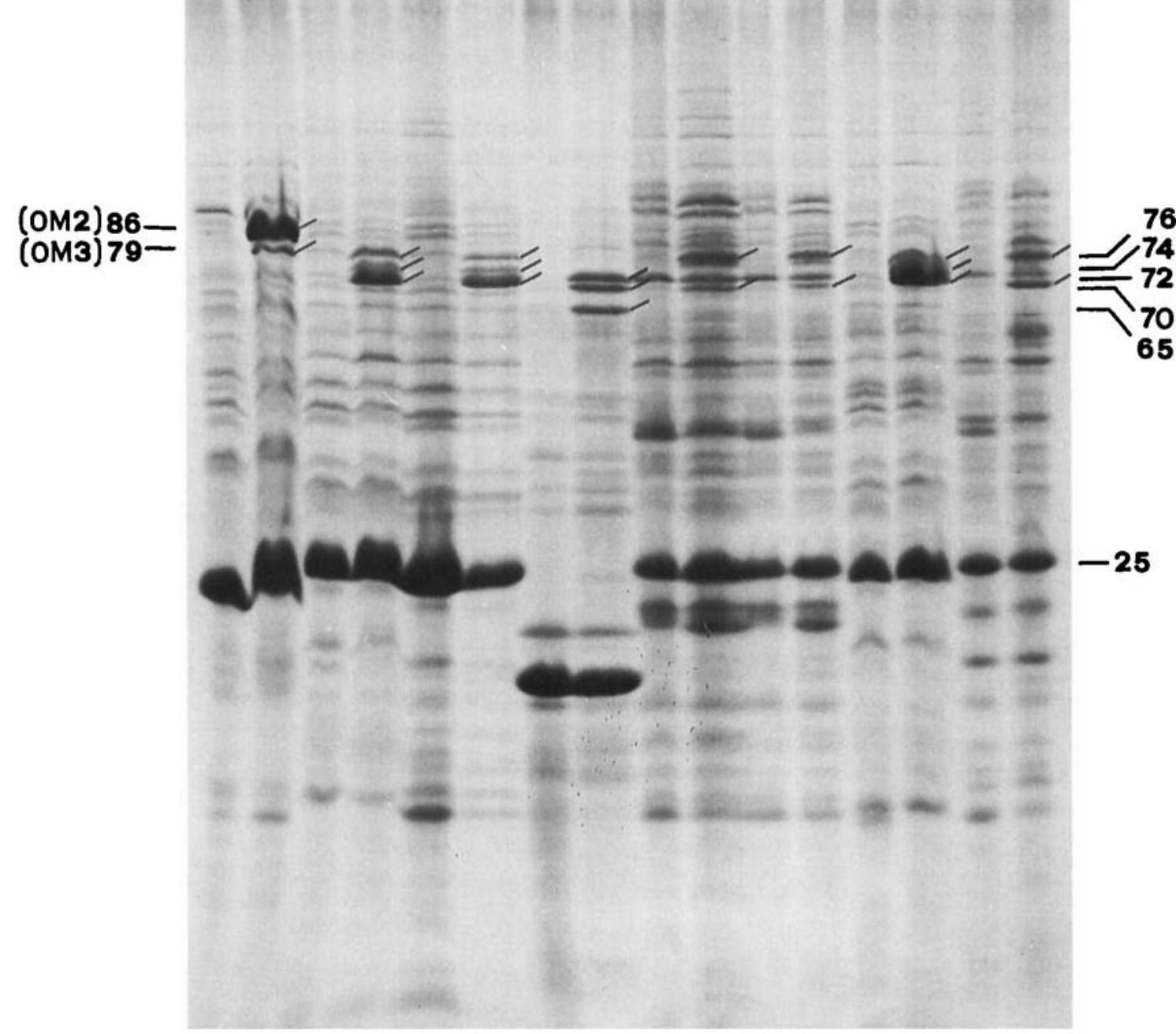

Figure. SDS-page of total cell envelopes of selected $V$. cholerae non-Ol strains with and without induction of outer-membrane proteins under iron limitation conditions: A, V. anguillarum $775 ; \mathbf{B}, V$. cholerae non-O1 M-17153; C, M-17151; D, D-17451; E, TK-17599, parental strain; F, tetracycline-sensitive derivative of TK-17599; G, D-17642; H, TK-17121; 1 indicates cells grown in medium containing $10 \mu \mathrm{M} \mathrm{FeCl}_{3} ; 2$ indicates cells grown under conditions of iron limitation. Some of the induced outer-membrane proteins are indicated by bars. The position of OM2 and OM3 proteins of the $V$. anguillarum 775 strain is shown as reference. Numbers indicate mol. wt in Kda. 
production of cholera toxin and, in contrast, some non-O1 Vibrio strains produce diarrhoea mediated by cholera toxin (CT) or CT-like toxins. ${ }^{1,5,26}$ The toxicity assays on $V$.cholerae non-O1 strains isolated from water in Bangladesh revealed a high percentage of toxigenic strains (table II). This finding differs from that of Twedt et al., ${ }^{2}$ in which none of the $V$. cholerae non-O1 strains tested was toxigenic. The fact that we have found non-cytotoxic strains with enterotoxin activity indicates that cytotoxicity tests alone do not permit detection of all the potentially pathogenic $V$. cholerae non-O1 strains in a sample. We have reported similar findings for environmental $V$. anguillarum and $A$. hydrophila strains. ${ }^{19,27,28}$

Only three of the enterotoxic and cytotoxic strains of $V$. cholerae non-O1 agglutinated human erythrocytes. This agglutination was found to be resistant to inhibition by D-mannose (table II) suggesting that this carbohydrate, or an analogue of it, is part of a receptor for bacterial adhesins in these strains. This type of haemagglutination is different from the D-mannose-sensitive haemagglutination reported in $V$. cholerae by Jones and Freter. ${ }^{29}$ The fact that other toxigenic strains were not haemagglutinating suggests that there is no correlation between toxin production and haemagglutinating activity in these $V$. cholerae non-O1 strains.

Although all cytotoxic Vibrio strains displayed haemolytic activity, it is not possible to state what role the haemolysins play in disease because, as previously reported, ${ }^{19}$ both pathogenic and nonpathogenic marine vibrios are able to produce them.

The analysis of plasmids in the Vibrio isolates revealed that strains containing either no plasmid or several different plasmids (table I) showed similar cytotoxic, enterotoxic and haemagglutinating activities (table II), indicating that these properties are not necessarily plasmid-mediated in all the strains. The transfer studies conducted to characterise the 115-Mda plasmid common to a group of toxigenic and non-toxigenic, multiresistant, $V$. cholerae nonO1 strains, allowed us to demonstrate that, in the toxigenic strains tested, this plasmid carried genes coding for kanamycin, streptomycin and sulphathiazole resistance and cytotoxin production but not enterotoxin production. However, the 115-Mda plasmid was associated with distinct phenotypic traits, because it was also carried by strains lacking cytotoxic or enterotoxic activities, or both, and with different antibiotic resistance patterns.

The availability of host iron has been proposed as a contributory factor in infections caused by diverse bacterial pathogens. The growth of pathogenic strains in low-iron medium can induce the synthesis of new outer-membrane proteins, some of which constitute a surface receptor for the siderophores. ${ }^{25,30-32}$ In this study, some $V$. cholerae nonO1 strains were able to grow under iron-limiting conditions and the synthesis of at least two new outer-membrane proteins was induced thereby (figure). However, the fact that the non-toxigenic vibrios examined also showed the same properties indicates that the iron-sequestering system is not the only factor playing a role in the toxigenicity of these $V$. cholerae non-O1 strains.

Analysis of total cell-envelope proteins revealed the presence of a major outer-membrane protein of $25 \mathrm{Kda}$ common to the majority of the Vibrio strains examined (figure). Interestingly, this protein was also detected in all the $V$. cholerae as well as in the $V$. cholerae non-O1 strains studied by Manning $e t$ $a l^{33}$ The outer-membrane-protein analysis also provided a useful tool to determine relatedness between strains. Thus, strains with comparable cytotoxic, enterotoxic, haemagglutinating and haemolytic activities (M-17151, M-17153 and D-17642) yielded the same iron-limitation induced outermembrane-protein patterns (figure).

From the results reported here, we conclude that, as with other vibrios, ${ }^{25,27,31,34}$ factors associated with virulence in $V$. cholerae non-O1 strains can be determined by chromosomal- or plasmid-borne genes, depending on the strain. Furthermore, the detection in some $V$. cholerae non-O1 strains of cytotoxic activity and drug resistance coded by a plasmid transferable to enteric bacteria as well as to environmental Aeromonas and Vibrio strains, is a matter of concern for public health.

This work was supported by grants from the National Science Foundation-Systematics nos. DEB-77-14646 and DEB-8208418; Office of Naval Research no. NOOA 14-18-K0648; National Institutes of Health no. 5R22-AI-14242; and World Health Organization C6/181/70. Y. Santos acknowledges a Research Fellowship from the Ministerio de Educación y Ciencia (MEC). 


\section{REFERENCES}

1. Kaper J, Lockman H, Colwell RR, Joseph SW. Ecology, serology and enterotoxin production of Vibrio cholerae in Chesapeake Bay. Appl Environ Microbiol 1979; 37: 91-103.

2. Twedt RM, Madden JM, Hunt et al. Characterization of Vibrio cholerae isolated from oysters. Appl Environ Microbiol 1981 ; 41: 1475-1478.

3. Lee JV, Bashford DJ, Donovan TJ, Furniss AL, West PA. The incidence of Vibrio cholerae in water, animals, and birds in Kent, England. J Appl Bacteriol 1982; 52: 281291.

4. Rhodes JB, Smith HL, Ogg JE. Isolation of non-O1 Vibrio cholerae serovars from surface waters in western Colorado. Appl Environ Microbiol 1986; 51: 1216-1219.

5. Roberts NC, Siebeling RJ, Kaper JB, Bradford HB. Vibrios in the Louisiana Gulf Coast environment. Microbiol Ecol 1982; 8: 299-312.

6. Huq A, Small EB, West PA, Huq MI, Rahman R, Colwell RR. Ecological relationships between Vibrio cholerae and planktonic crustaceans copepods. Appl Environ Microbiol 1983; 45: 275-283.

7. Venkateswaran K, Kiiyukia C, Takaki M et al. Characterization of toxigenic vibrios isolated from the freshwater environment of Hiroshima, Japan. Appl Environ Microbiol 1989; 55: 2613-2618.

8. Blake PA, Weaver RE, Hollis DG. Diseases of humans (other than cholera) caused by vibrios. Annu Rev Microbiol 1980; 34: 341-367.

9. Wilson R, Lieb S, Roberts A et al. Non-O Group 1 Vibrio cholerae gastroenteritis associated with eating raw oysters. Am J Epidemiol 1981; 114: 293-298.

10. Glass RI, Becker S, Huq MI et al. Endemic cholera in rural Bangladesh. Am J Epidemiol 1982; 116: 959-970.

11. Yamanoi H, Muroga K, Takahashi S. Physiological characteristics and pathogenicity of NAG Vibrio isolated from diseased ayu. Fish Pathol 1980; 15: 69-73.

12. Gyobu Y, Kodama H, Uetake H, Katsuda S. Studies on the enteropathogenic mechanism of non-O1 Vibrio cholerae isolated from the environment and fish in Toyama prefecture. Microbiol Immunol 1984; 38: 735-745.

13. Yamamoto K, Takeda Y, Miwatani T, Craig JP. Evidence that a non-O1 Vibrio cholerae produces enterotoxin that is similar but not identical to cholera enterotoxin. Infect Immun 1983; 41: 896-901.

14. Datta-Roy K, Banerjee K, De SP, Ghose AC. Comparative study of expression of hemagglutinins, hemolysins and enterotoxins by clinical and environmental isolates of non-O1 Vibrio cholerae in relation to their enteropathogenicity. Appl Environ Microbiol 1986; 52: 875-879.

15. Spira WM, Fedorka-Cray PJ, Pettebone P. Colonization of the rabbit small intestine by clinical and environmental isolates of non-O1 Vibrio cholerae and Vibrio mimicus. Infect Immun 1983; 41: 1175-1183.

16. Datta-Roy K, Dasgupta C, Ghose AC. Hemagglutination and intestinal adherence properties of clinical and environmental isolates of non-O1 Vibrio cholerae. Appl Environ Microbiol 1989; 55: 2430-2406.

17. West PA, Colwell RR. Identification and classification of Vibrionaceae : an overview. In: Colwell RR (ed) Vibrios in the environment. New York, Wiley. 1984: 285-364.
18. Nishibuchi $\mathbf{M}$, Seidler RJ. Medium-dependent production of extracellular enterotoxins by non-O1 Vibrio cholerae, Vibrio mimicus and Vibrio fluvialis. Appl Environ Microbiol 1983; 45: 228-231.

19. Toranzo AE, Barja JL, Colwell RR, Hetrick FM, Crosa JH. Haemagglutinating, haemolytic and cytotoxic activities of Vibrio anguillarum and related vibrios isolated from striped bass on the Atlantic Coast. FEMS Microbiol Lett 1983; 18: 257-262.

20. Duguid JP. Fimbriae and adhesive properties in Klebsiella strains. J. Gen Microbiol 1959; 21: 271-286.

21. Kado CI, Liu ST. Rapid procedure for detection and isolation of large and small plasmids. $J$ Bacteriol 1981 ; 145: 1365-1373.

22. Toranzo AE, Barja JL, Colwell RR, Hetrick FM. Characterization of plasmids in bacterial fish pathogen. Infect Immun 1983; 39: 184-192.

23. Toranzo AE, Combarro $P$, Lemos ML, Barja JL. Plasmid coding for transferable drug resistance in bacteria isolated from cultured rainbow trout. Appl Environ Microbiol 1984; 48: 872-877.

24. Crosa JH, Hodges LL. Outer membrane proteins induced under conditions of iron limitation in the marine fish pathogen Vibrio anguillarum 775. Infect Immun 1981; 31: 223-227.

25. Toranzo AE, Barja JL, Potter SA, Colwell RR, Hetrick FM, Crosa JH. Molecular factors associated with virulence of marine vibrios isolated from striped bass in Chesapeake Bay. Infect Immun 1983; 39: 1220-1227.

26. Craig JP, Yamamoto K, Takeda Y, Miwatani T. Production of cholera-like enterotoxin by a Vibrio cholerae non-O1 strain isolated from the environment. Infect Immun $1981 ; 34: 90-97$.

27. Toranzo AE, Santos $\mathbf{Y}$, Lemos ML, Ledo A, Bolinches J. Homology of Vibrio anguillarum strains causing epizootics in turbot, salmon and trout reared on the Atlantic Coast of Spain. Aquaculture 1987; 67: 41-52.

28. Santos Y, Toranzo AE, Barja JL, Nieto TP, Villa TG. Virulence properties and enterotoxin production of Aeromonas strains isolated from fish. Infect Immun 1988; 56: 3285-3293.

29. Jones GW, Freter R. Adhesive properties of Vibrio cholerae : nature of the interaction with isolated rabbit brush border membranes and human erythrocytes. Infect Immun 1976; 14: 240-245.

30. Bullen JJ, Rodgers HJ, Griffiths E. Role of iron in bacterial infection. Curr Top Microbiol Immunol 1978; 80: 1-35.

31. Crosa JH. The relationship of plasmid-mediated iron transport and bacterial virulence. Annu Rev Microbiol 1984; 38: 69-89.

32. Griffiths $\mathrm{E}$. The iron uptake systems of pathogenic bacteria. In: Bullen JJ, Griffiths E (eds) Iron and infection. Chicester, Wiley. 1987: 69-137.

33. Manning PA, Imbesi F, Haynes DR. Cell envelope proteins in Vibrio cholerae. FEMS Microbiol Lett 1982; 14: 159166.

34. Lemos ML, Salinas P, Toranzo AE, Barja JL, Crosa JH. Chromosome-mediated iron uptake system in pathogenic strains of Vibrio anguillarum. J Bacteriol 1988; 170: $1920-1925$. 